\title{
O wielość narracji, za pluralizm relacji
}

TEKST BARTŁOMIEJA KAPICY - polemiczny wobec opublikowanego jest wręcz modelowym przykładem tego, jak określone słowa, czy pojęcia potrafią zamknąc odbiorcę na istotę przekazu. „Stan wojenny”, „Okrągły Stół”, czy właśnie „Poznański Czerwiec” sprawiają, że treść dotykającej takiej problematyki pracy, staje się przedmiotem niekoniecznie percepcji, a raczej twórczej interpretacji. Tym samym, pragnę wyjaśnić, dlaczego odnoszę wrażenie, iż polemika Pana B. Kapicy dotyczy w większym stopniu jego wyobrażenia o moich intencjach, niż samej treści artykułu.

Po pierwsze, czuję się zobligowana objaśnić, stosując określenie B. Kapicy, „mętny tytul” mojego tekstu. W nawiązaniu do tematu przewodniego poprzedniego wydania „Refleksji”, a więc „opozycji i opozycyjności” postanowiłam w swoim artykule, dotyczącym pamięci zbiorowej o Czerwcu '56, zwrócić uwagę właśnie na te dwa aspekty. Jedną z najistotniejszych cech pamięci jest bowiem fakt, iż często stanowi ona wypadkową nad wyraz opozycyjnych wobec siebie narracji. W przypadku Czerwca '56 pierwsza z nich to swoisty „mit opozycji”, czy „mit o opozycji” - określa ona uczestników wydarzeń mających miejsce 28 czerwca 1956 r. jako „powstańców”, „ofiary systemu totalitarnego", a samo wydarzenie nazywa „antykomunistycznym powstaniem”. Przeciwstawna jej narracja jest z kolei swoistą „opozycją do (tego) mitu” - sugeruje, iż Poznański Czerwiec był strajkiem na tle ekonomiczno-socjalnym lub zamieszkami o charakterze politycznym. Te dwie, tak różniące się od siebie interpretacje historycznych wydarzeń, skłoniły mnie do zaprezentowania składających się na nie elementów. Niestety, Pan B. Kapica uznał, iż efektem tych starań jest „niejasna konstrukcja tekstu”. By zmienić ten stan rzeczy, wypunktowuję poniżej poszczególne części artykułu: 1) wskazanie na zagadnienie wpływu charakteru polityki historycznej, przekazów medialnych, procesu komunikowania, czy szerzej; składowych pamięci upowszechnionej (wg Barbary Szackiej) na pamięć zbiorową w kontekście Poznańskiego Czerwca, 2) wskazanie różnorodności terminów określa- 
jących te historyczne wydarzenia, 3) ukazanie wielości typów relacji o Czerwcu '56 w poszczególnych okresach czasowych, ich obecności w dyskursie publicznym, czy naukowym, charakteru retoryki oraz cech szczególnych danej narracji.

Ustosunkowując się do dalszych zarzutów B. Kapicy nie uznaję, iż „bezzasadne jest rozpatrywanie narracji o Czerwcu '56 jako dychotomicznym zjawisku zamykającym się w schemacie $w$ opozycji do mitu i o micie opozycji”. Uważam, iż jest to interesująca propozycja dla szerszego i bardziej szczegółowego projektu badawczego. Za całkowicie nietrafiony uważam zarzut, iż jako autorka „wyciągałam bardzo daleko idące wnioski na temat sposobów postrzegania Czerwca w publikacjach nienaukowych na podstawie zawartości stron internetowych wikipedia.org, portalwiedzy.onet.pl, city.poznan.pl, poznan.pl”. Treści znajdujące się na tych stronach posłużyły mi jedynie wykazaniu, jakim terminem określane są wydarzenia z 28 czerwca 1956 r. w źródłach nienaukowych, czyli dostępnych niewątpliwie szerokiemu gronu odbiorców i kształtujących pamięć zbiorową. Wybrane strony były wynikiem ich pozycjonowania przez przeglądarkę Google, o czym informuję w artykule. Co więcej celem tej analizy było wyliczenie jak największej liczby terminów, którymi określany jest Poznański Czerwiec. Badaniu została poddana także treść ok. 20 publikacji naukowych, czy poularno-naukowych (w efekcie analizy przedstawiłam aż 18 różnych określeń stosowanych wobec wydarzeń z 28 czerwca 1956 r.). Oczywiście jestem świadoma tego, o czym pisze B. Kapica, „iż sposób postrzegania i opisywania Poznańskiego Czerwca był zmienny i zależał od wielu czynników”. Co więcej, o tym właśnie traktuje cały mój artykuł. Ponadto, w jego treści nie znajduje się sformułowanie, iż „lansowane w okresie PRL ujęcie Poznańskiego Czerwca tylko i wyłącznie jako strajku na tle ekonomicznym” jest „opozycją do mitu” (ta charakterystyka została przypisana narracji Łukasza Jastrząba i publikacjom zawierającym treści do niej zbliżone). Koniecznym wydaje mi się także odniesienie do stwierdzenia B. Kapicy, iż „sam sposób postrzegania rewolty w Poznaniu przez władzę komunistyczną, tylko w tak krótkim okresie jak czerwiec-październik 1956 ulegał gwałtownym zmianom" oraz do zwróconej przez niego uwagi, iż brakuje o tym informacji w artykule. Owszem, brakuje. Co więcej dodam, iż w artykule brakuje jeszcze wielu innych informacji, trudno bowiem na 15 stronach tekstu zawrzeć wszystko, co w ogóle napisano o Czerwcu '56. W mojej ocenie nie stanowi to jednak o defekcie pracy, bowiem artykuł naukowy powinien wskazywać na pewne aspekty, dokonywać analizy, czy postawić 
problem badawczy, a nie stanowić wierną kopię dotychczas już napisanych tekstów.

Nie uważam także, aby „błędnym było twierdzenie, że doszukiwanie się w Czerwcu '56 elementów powstańczych można zaliczyć do narracji kreującej mit”. Zwłaszcza, że nie zakładam, iż słowo „mit” nacechowane jest pejoratywnie i stanowi fałszywy przekaz. W całym tekście jest ono używane zgodnie z jego etymologią, czyli jako „legenda, opowieść" - tu o zorganizowanej, świadomej antykomunistycznej opozycji albo jej braku.

Nie mogę się także zgodzić z B. Kapicą, iż książka Ł. Jastrząba „Rozstrzelano moje serce $w$ Poznaniu”. Poznański Czerwiec 1956 r.straty osobowe $i$ ich analiza nie stanowi „nowej jakości w postrzeganiu istoty Czerwca'56". Wręcz przeciwnie, stanowi nie tylko novum, ale jest istotną, znaczącą i ważną publikacją wobec kilkudziesięciu innych, niemalże zbliżonych do siebie treścią, a wciąż wydawanych, pozycji. Jastrząb nie tylko dokonuje analizy strat osobowych (te kwestie nie zelektryzowałaby w taki sposób poznańskiej opinii publicznej, jak miało to miejsce po wydaniu książki), ale odbrązawia Czerwiec '56. Wskazuje na nieprawidłowości w związkach skupiających kombatantów Poznańskiego Czerwca, poddaje refleksji takie „dogmaty” jak oczywistość pierwszego strzału, czy historię skrwawionego sztandaru, wykazuje wysoki stopień przypadkowość wielu zranień, czy nawet śmiertelnych ofiar Poznańskiego Czerwca, przypomina o ulicznych samosądach na pracownikach Urzędu Bezpieczeństwa, w tym o śmiertelnie pobitym wartowniku Wojewódzkiego Urzędu ds. Bezpieczeństwa Publicznego. Powyższe kwestie, pomijane lub marginalizowane $\mathrm{w}$ innych opracowaniach, stanowią więc istotne novum i w mojej ocenie stanowią kolejną, nową narrację o Czerwcu '56.

B. Kapica zarzuca mi także, iż użyta przeze mnie metoda badawcza „zwalnia od obowiązku ustosunkowania się wobec prawdziwości danej narracji bądź składających się na nią elementów (gdyż celem jest tylko rekonstrukcja obrazu)”. Ależ oczywiście, że tak. Co więcej nie znajduję w sobie ani kompetencji ani chęci do tego bym dokonywała oceny „prawdziwości” jednej, czy drugiej narracji. Jestem wręcz niereformowalnie przeświadczona o niemożności bycia depozytariuszem prawdy.

Czuję się także w obowiązku ustosunkować do zarzutu „nie posiadania erudycji w zakresie funkcjonowania historiografii PRL, a także związanego z tym zagadnieniem problemu tzw. historyków resortowych”. Odnoszę wrażenie, że uważne przeczytanie mojego artykułu, gwarantuje zauważenie, iż przytaczane przeze mnie słowa Jana 
Ptasińskiego, są jedynie komentarzem dla opublikowanych w jego książce zeznań, jakie przed organem sprawiedliwości złożyła Stanisława Sobańska - jedna z ikon Poznańskiego Czerwca. Mam nadzieję, że te w ocenie B. Kapicy nie są już „enuncjacjami” nieposiadającymi „wartości epistemologicznej”?

Ponadto całkowicie nie rozumiem, co B. Kapica miał na myśli sugerując, iż podważam fakt historyczny, jakim było odniesienie się przez protestujących do religii. Szczególnie, że zarzut ten B. Kapica stawia wobec akapitu, w którym poruszam kwestię podkreślania religijnego wymiaru protestu i wymieniam poszczególne wydarzenia, które to czyniły (np. dodanie podczas renowacji pomnika "Czerwiec '56" frazy „O Boga” obok napisu „Za wolność, prawo i chleb”, wmurowanie obok tablicy przypominającej, że modlił się tam Jan Paweł II, obecność na spotkaniu „Lednica 2006” przedstawicieli aż trzech związków kombatanckich, uczynienie motywem przewodnim drogi krzyżowej wydarzeń Czerwca '56). Nie wskazuję ponadto, jak sugeruje B. Kapica, iż „w opracowaniu o charakterze naukowym Poznański Czerwiec '56 - sens pamięci tylko jeden artykuł porusza tę kwestię (religijnego wymiaru protestu, przyp. red. J. K.)", ale zwracam uwagę, iż w wydanej przez UAM publikacji, składającej się z zaledwie kilku rozdziałów, jeden (aż jeden) jest autorstwa zakonnika i nosi następujący tytuł „Czas jako mowa Boga. Teologia historii Jana Pawła II”. Trudno zaprzeczyć, że jego bezpośrednie powiązanie z tematyką Czerwca '56 nie jest wprost uchwytne, niemniej stanowi istotny przykład podkreślania w publikacjach typu „mit o opozycji”, religijnych inklinacji protestu.

Kolejny zarzut B. Kapicy, sugerujący iż w swoim tekście analizowałam jedną konkretną narrację tworzoną przez jedną konkretną osobę, także uważam za nietrafiony. Treść artykułu obrazuje przecież, jak różnie mogą być rozkładane akcenty badawcze, i tym samym jaką zbiorczą narrację mogą tworzyć. A zatem, przywołany Jerzy Eisler uzupełniając swoją pracę o kolejne informacje, czy też nawet podważając te wcześniej zawarte, nie tworzy żadnej nowej, osobnej i tylko jemu przynależnemu narracji. On, wraz z wieloma innymi badaczami, pracującymi w oparciu o nowe źródła, czy znajdującymi się pod wpływem określonych trendów (np. postulatu przywracania pamięci o kobietach - bohaterkach danych wydarzeń), tworzą kolejną narrację, poprzez zróżnicowanie przekazu, ubogacając wiedzę na dany temat.

Kończąc, pokładam głęboką nadzieję, że zarysowane przez polemikę Pana B. Kapicy różnice obieranych przez historyka, a politologa perspektyw badawczych, czy metod badawczych, przestaną już niedłu- 
go stanowić podstawę do jakiegokolwiek sporu. Co więcej, staną się pozytywem, którego efektem będzie wielość narracji. Ta wielość bowiem w mojej ocenie posiada wysoki walor poznawczy oraz przyznaje odbiorcy prawo do myślenia.

\section{NOTA O AUTORCE}

Joanna Kałużna [joanna.kaluzna@gmail.com] - studentka V roku politologii oraz II roku stosunków międzynarodowych na Wydziale Nauk Politycznych i Dziennikarstwa Uniwersytetu im. Adama Mickiewicza w Poznaniu. Współorganizatorka międzywydziałowej konferencji „Płeć. Polityka. Wybory” oraz ogólnopolskiej konferencji „Przestrzeń publiczna, przestrzeń prywatna, przestrzeń kobieca”. Współzałożycielka Koła Naukowego Studiów Genderowych. Swoją działalność naukową skupia na problematyce polskiej drogi do transformacji systemowej oraz na zagadnieniu pamięci upowszechnionej wobec okresu Polski Ludowej. 